\title{
Partial Stapled Hemorrhoidopexy Versus Circular Stapled Hemorrhoidopexy
}

\author{
Jin Sub Kim \\ Good Morning Coloproctology Clinic, Seoul, Korea
}

\section{See Article on Page 28-34}

A stapled hemorrhoidopexy ( $\mathrm{SH})$ is a recently rising therapy and is widely performed. Side effects, such as anal stenosis, rectal stenosis, and fecal urgency, have been continuously associated with the practical uses of the $\mathrm{SH}$, despite its having many advantages [1-4], including remarkably decreased anal pain after surgery, shortened recovery periods, and faster resumption of normal activities, compared to the previously used conventional hemorrhoidectomy [5-7]. On this point, this essay, which is the subject of this editorial, has great meaning in its reporting of initial results on the use of a partial stapled hemorrhoidopexy (PSH), which is a new version of the $\mathrm{SH}$ that was designed to reduce, and hopefully eliminate, the disadvantages associated with the old version of the $\mathrm{SH}$ [8-12].

In the $\mathrm{PSH}$ procedure, a selective purse-string suturing of prolapsed hemorrhoid tissues is performed using a specifically produced window connected to an anoscope, after which the hemorrhoids are removed with the same auto-suturing device as that used in the old version of the $\mathrm{SH}$, and normal mucosa is supplied to the excision sites [13]. Also, the PSH is known thought to have few side effects, such as stenosis and fecal urgency, because of its using fewer staples than the $\mathrm{SH}$, but this has yet to be confirmed but none is yet certainly identified for it. Most SH practitioners report that side effects hardly occur when the basic principles of SH surgery are followed: for example, not positioning the stapling lines in the anal canal, not excising excessive anal mucosa from the lower rectum, and proper anastomosis except for muscle layers $[1,3,4]$. Therefore, surgeons must have basic technical expertise with the use of a SH before performing a PSH.

Correspondence to: Jin Sub Kim, M.D.

Good Morning Coloproctology Clinic, 204 Bongeunsa-ro, Gangnam-gu, Seoul 06135, Korea

Tel: +82-2-558-6625, Fax: +82-2-558-6635, E-mail: joseph-dr@hanmail.net

(c) 2017 The Korean Society of Coloproctology

This is an open-access article distributed under the terms of the Creative Commons Attribution NonCommercial License (http://creativecommons.org/licenses/by-nc/4.0) which permits unrestricted noncommercial use, distribution, and reproduction in any medium, provided the original work is properly cited.
Because of the lack of a consensus concerning the specific name to be used when referring to the PSH, each essay uses a different term when referring to the PSH, even though the meanings are similar. During the early period of its use, the $\mathrm{SH}$ was referred to as the norm of circular stapled hemorrhoidectomy; later that changed to the $\mathrm{SH}$, which is the term currently used in many discussions [12, 14]. Likewise, the surgical method using a tissue-selective stapler is also referred to by various names: a PSH, a tissueselective technique (TST), a tissue-selecting therapy, etc. Also, whether the procedure should be called a hemorrhoidectomy or a hemorrhoidopexy based on the excision amount and the location of the excision has not been discussed. Thus, further in-depth discussions are required so that the terms used in this area of surgery are properly defined. Also, as this essay pointed out, few long-term follow-up and comparative studies have been done on the disadvantages of a $\mathrm{PSH}$, including recurrence and hemorrhage, or, especially, on the methods for processing the dog-ear that is formed after mucosal bridge dissociation [8, 9, 11-13]. Thus, further prospective studies comparing the $\mathrm{SH}$ to the $\mathrm{PSH}$ are needed.

\section{CONFLICT OF INTEREST}

No potential conflict of interest relevant to this article was reported.

\section{REFERENCES}

1. Longo A. Treatment of hemorrhoids disease by reduction of mucosa and hemorrhoidal prolapse with a circular stapler suturing device: a new procedure. In: Proceedings of the 6th World Congress of Endoscopic Surgery; 1998 Jun 3-6; Rome, Italy. Bologna: Monduzzi Editore; 1998. p. 777-84.

2. Laughlan K, Jayne DG, Jackson D, Rupprecht F, Ribaric G. Stapled haemorrhoidopexy compared to Milligan-Morgan and Ferguson haemorrhoidectomy: a systematic review. Int J Colorectal Dis 2009;24:335-44.

3. Yun KJ, Cho HC. Clinical experience with a circular stapled hemorrhoidopexy without circular anal dilator (CAD). J Korean Soc 


\section{Coloproctol 2007;23:431-6.}

4. Kim JS. Circular stapled hemorrhoidectomies in the treatment of hemorrhoids. J Korean Soc Coloproctol 2004;20:240-8.

5. Park YJ. Pneumoretroperitoneum after procedure for prolapsed hemorrhoid. Ann Coloproctol 2013;29:256-8.

6. Lee KY. Complications after stapled hemorrhoidopexy. J Korean Surg Soc 2005;68:327-31.

7. Wong LY, Jiang JK, Chang SC, Lin JK. Rectal perforation: a lifethreatening complication of stapled hemorrhoidectomy: report of a case. Dis Colon Rectum 2003;46:116-7.

8. Lin HC, He QL, Ren DL, Peng H, Xie SK, Su D, et al. Partial stapled hemorrhoidopexy: a minimally invasive technique for hemorrhoids. Surg Today 2012;42:868-75.

9. Lin HC, Ren DL, He QL, Peng H, Xie SK, Su D, et al. Partial stapled hemorrhoidopexy versus circular stapled hemorrhoidopexy for grade III-IV prolapsing hemorrhoids: a two-year prospective controlled study. Tech Coloproctol 2012;16:337-43.

10. Lin HC, Luo HX, Zbar AP, Xie SK, Lian L, Ren DL, et al. The tis- sue selecting technique (TST) versus the Milligan-Morgan hemorrhoidectomy for prolapsing hemorrhoids: a retrospective casecontrol study. Tech Coloproctol 2014;18:739-44.

11. Wang ZG, Zhang Y, Zeng XD, Zhang TH, Zhu QD, Liu DL, et al. Clinical observations on the treatment of prolapsing hemorrhoids with tissue selecting therapy. World J Gastroenterol 2015;21: 2490-6.

12. Jeong H, Hwang S, Ryu KO, Lim J, Kim HT, Yu HM, et al. early experience with a partial stapled hemorrhoidopexy for treating patients with grades III-IV prolapsing hemorrhoids. Ann Coloproctol 2017;33:28-34.

13. Lin HC, Lian L, Xie SK, Peng H, Tai JD, Ren DL. The tissue-selecting technique: segmental stapled hemorrhoidopexy. Dis Colon Rectum 2013;56:1320-4.

14. Corman ML, Gravié JF, Hager T, Loudon MA, Mascagni D, Nyström PO, et al. Stapled haemorrhoidopexy: a consensus position paper by an international working party - indications, contra-indications and technique. Colorectal Dis 2003;5:304-10. 